\title{
STRATEGIC ADAPTATION AND THE VALUE OF FORECASTS: THE DEVELOPMENT OF A CONCEPTUAL FRAMEWORK
}

\author{
Faizal Mohamed Yusof ${ }^{1}$, Rozainun Abdul Aziz ${ }^{2}$ \\ MARA University of Technology, Malaysia \\ E-mail: 1nicktalbot2004@yahoo.co.uk; ${ }^{2}$ rozainun@salam.uitm.edu.my \\ Received 12 November 2007; accepted 19 March 2008
}

\begin{abstract}
This paper examines the lack of emphasis on the value of forecasts in strategic adaptation frameworks. The objective of this paper is to offer a conceptual framework of strategic adaptation that incorporates and emphasizes the value of forecasts. In developing the framework, we incorporate three different studies. Eunni's model (2003) purports to rank companies with high strategic adaptation ability in an industry. Further, in developing our framework, we specifically link the contributions of Lawrence et_al. (2006) and Mentzer et al. (1996, 1999).

Our study highlights that companies with high strategic adaptation ability need to be examined further in order to understand and take on board how they withstand the volatile market. It is intended that the conceptual framework, driven by previous studies and the current scenario, will offer a better direction for companies to adapt towards an objective indicator of the value of forecasts for strategic purposes.
\end{abstract}

Keywords: Strategic adaptation, forecasting, management accounting, capabilities, uncertainties, benchmarking, globalization.

\section{Introduction}

The aim of this paper is to provide a sound basis to support a scientific approach in investigating strategic adaptation towards the value of forecasts. This paper attempts to integrate literature from three disciplines, namely management accounting, strategic adaptation and forecasting with a view to producing a conceptual framework for researchers exploring the value of forecasts. From the outset, we highlight that the subject of forecasting is extremely topical in business organizations. For example, the new millennium has witnessed the largest single failure in US corporate history, and perhaps the ultimate crime of corporate social irresponsibility. Could the future of Enron have been predicted under the changing business climate at that time? Just as the climate change made the most successful predator on this planet, the dinosaurs extinct, arguably a change in the business climate and associated behaviours made Enron extinct. This incident emphasizes the need to develop models that allow for a more accurate prediction of the inevitable changes and uncer- tainties in the business (Michaluk 2002). Reform must encompass wider issues that emphasize the ability of an organization to predict and forecast the uncertain future which globalization has brought about. Globalization has spurred mergers and acquisitions as well as downsizing of business organizations. The survival of businesses very much depends on the world as well as country-specific economic fluctuations. This situation increases uncertainty of the future leading to great concern within any business organization. In view of the uncertainties, businesses need to develop capabilities to ensure their survival. Despite organizing carefully the business activities and assigning responsibilities with tight policies and control systems in place, businesses face the challenge of adapting to these dynamic run. As such, the basic tools of management become imperative in ensuring performance. Nevertheless, being forward-looking in an organization plays an important role in initiating and benchmarking changes. We will look at the issue of forward-looking in the context of planning. 
The concept of planning pervades in three disciplines which make up the core structure of this study: Management Accounting, Strategic Adaptation, and Forecasting. First, the importance of forward-looking in Management Accounting has received increasing attention in the light of defining the role of accountants. The next generation of accountants needs to be adept in knowledge management, forecasting and optimization techniques (IFAC 1998; Shaw 2007). Second, Strategic adaptation (SA) ability involves the ability of an organization to cope with new realities in its operating environment. This concept has been used to explain why some companies succeed and sustain competitive advantage, and others fail. An important component in explaining strategic adaptability is strategic planning. Strategic planning has long asserted that formal planning provides benefits that ultimately produce economic value (Steiner 1979; Thompson \& Strickland 1987). One principal element in strategic planning is forecasting, which has been consistently recognized as an important capability for business planning and management (Makridakis \& Wheelwright 1977; Armstrong 1987; Cox 1987; Wright 1988; Cox 1989; Fildes \& Hastings 1994; J. T. Mentzer \& Gomes 1994; Sanders \& Mandrodt 1994; Aziz-Khairulfazi 2004). Third, forecasting can simply be defined as predicting the future. In 2007, Dr Patrick Dixon, regarded as the 'Global change Guru' by the Wall Street Journal and Europe's leading Futurist (Press Association) quotes, "Either we take hold of the future or the future will take hold of us". The importance of forecasting must not be undermined especially in the era of globalization.

This paper aims to present a workable framework of strategic adaptation ability with forecasting management. It will also provide a new extension of IFAC Management Accounting Framework for capabilities (IFAC 1998).

\section{Literature review}

\subsection{Evolution of strategic adaptation}

In the literature of strategic adaptation, there are at least three schools of thoughts which have evolved over time that emphasized different predominant factors influencing the strategic adaptation of organizations. One school of thought emphasized on the predominant role of the environment. There are numerous studies conducted under this school of thought amongst others, Powell and Dimaggio (1991), who concluded that cultural-institutional environment is important in shaping organization strategic choice. The second school of thought is the resource-based view (RBV) which explains differential firm success by investigating factors internal to the firm. The prominent studies are conducted under this school of thought amongst others, Prahalad and Hamel (1990) and Teece et al. (1997). The third school of thought is the integrative view. This view reconciles the two competing perspectives and conceptualizes organizational adaptation as the result of internal adjustments and actions oriented to the environment (Venkaratman 1990; Child 1997). Eunni (2003) has further explored this view by underlining the relationship between strategic adaptation and organizational performance. The study conceives that strategic adaptation ability consists of two kinds of fit or alignment: the alignment of structures and processes within the firm (internal alignment) and the alignment of the firm as a whole with the environment in which it operates (external alignment). Thus, differences in performance among firms operating in an environment can be related to the differences in the degrees of the two kinds of alignment exhibited by them. The proposed framework conceptualizes that most adaptive firms in the industry (high performers) possess a higher degree of internal and external alignments.

\subsection{Strategic adaptation, strategic planning and forecasting}

The resource-based view has long argued that the key to economic rents lies in the firm's capabilities or competencies - sustainable organizational abilities based in the firm's capabilities or competencies (Prahalad \& Hamel 1990; Barney 1991; Porter 1996). Barney (1986) argued that the key to earning sustainable above normal returns is through superior forecasting, while Makridakis et al. (1998) argued that firm performance often critically depends on forecasting accuracy in firm's planning. As Makadok and Walker (2000) explain, nearly every function of the firm relies on some form of forecasting. Forecasting is also a critical element in the evolutionary theory of the firm (Nelson \& Winter 1982) and the dynamic capabilities literature. Teece (2000) describes the importance of "external sensing" of opportunities and threats as the first step in a firm's development of dynamic capabilities. Firms must anticipate and adapt to environment changes in order to hold any sustainable advantage over their competitors.

The fact that the firm's environment is characterized by a high degree of risk and uncertainty provides the principle rationale for the use of strategic planning and forecasting. It is the driving force underlying any strategic plan (Naylor 1983). 


\subsection{Evolution of forecasting}

Forecasting is a systematic process of decisions and actions performed in an effort to predict the future (Cleary \& Lavenbach 1982). It has input and output just like a production operation (Wallace 1996). Significant developments have been made in the literature of forecasting. It has evolved from looking at forecasting as a model or technique in isolation to a view of forecasting and its interaction with management and other functions in the organization (Smith 2000). The evolution has been summarized by Armstrong (1986a) in three categories of interest: 1) making forecasts, 2) estimating uncertainty, and 3) gaining acceptance. Two of these areas, making forecasts and estimating uncertainty, are concerned with specific aspects of model development and assessment. The third area begins to address behavioral (judgmental) and managerial considerations in the application of forecasting models.

It is generally recognized that without management judgment in forecasting, serious problems can result. Worthen (2003) describes Nike's $\$ 400$ million experiment with forecasting software which went disastrously wrong. As a result, there were massive inventory write-offs due to the system's inaccuracy and lack of management input. Good forecasting requires that management judgment play its role and, equally important, that there be effective implementation of the forecasting systems (Fildes \& Hastings 1994). The most notable study in the area of forecasting management is by Menzter et al. $(1996,1999)$. He developed the Sales Forecasting Benchmarking Model (SFBM) which explained the managerial aspects of forecasting. It consists of four original dimensions; 1) functional integration, 2) approach, 3) systems and 4) performance measurement. In a complementary study, Green (2001) incorporated additional variables (level of accuracy of sales forecast and level of managers' satisfaction with the sales forecasting process). She identified the additional variables (Menzter \& Cox 1984; Menzter \& Kahn 1995; Ginevičius, Korsakienè 2005) as having a relationship with the four dimensions mentioned earlier. In a review of the last 25 years of forecasting research in management judgment Lawrence et al. (2006) highlighted the increasing importance of management involvement in the forecasting process. He underlined the need for a study to signify the value forecasts in business organizations.

\subsection{Evolution of management accounting}

The field of organizational activity encompassed by management accounting has developed through four recognizable stages (IFAC 1998) as depicted in figure (four). If the management accounting evolution had been accordingly planned and implemented by organizations, most companies would have achieved their value creation stage by today. Unfortunately, studies made by Johnson and Kaplan (1987) revealed that management accounting function had 'lost its relevance'. Proactive measures must therefore be taken to 'regain its role'. Currently due to globalization and rapid changes in the business environment, most companies have gone further to the next step, which is on strategic focus and risk management. Interestingly, in October 2002, the IFAC Board explored the emerging concept of 'Enterprise Governance' which, it could be argued, extended their conceptual accounting framework (IFAC 1998) which had previously described management in terms of 1) the function of MA in organizations; 2) the utility of outcomes of MA process; 3) criteria to assess the value of processes and technologies in MA process, and 4) capabilities for effective MA functions.

This paper is an extension of management accounting evolution which emphasizes on effective use of resources and the management being proactive. During this stage the concept of strategic management accounting (SMA) begins to take prominence. SMA is a form of forward-looking management accounting in which emphasis is placed on information which relates to factors external to the firm, as well as non-financial internally generated information (CIMA 2000). This paper is also in line with the management accounting framework, "capabilities required for function effectiveness". Forecasting has been consistently recognized as an important capability for business planning and management (Makridakis \& Wheelwright 1977; Armstrong 1987; Cox 1987; Wright 1988; Cox 1989; Fildes \& Hastings 1994; Mentzer \& Gomes 1994; Sanders \& Mandrodt 1994; Aziz-Khairulfazi 2004).

From the above, it can be seen that the literature review raises several issues from recent studies with regard to forecasting and strategic adaptation. The evolution of management accounting highlighted the increasing importance of organizations to be forward-looking and therefore increasingly involved in forecasting. The under-emphasis of forecasting has been underlined by a recent article in CIMA's official magazine (Shaw 2007). The literature review of strategic adaptation highlighted the importance of strategic planning but under-emphasized the function of forecasting in the framework. The fact remains that forecasting is an important capability for business planning and management (Makridakis \& Wheelwright 1977; Armstrong 1987; Cox 1987, 1989; Wright 1988; Fildes \& Hastings 1994; Mentzer \& Gomes 1994; Sanders \& Mandrodt 1994; Aziz-Khairulfazi 2004; Lawrence et al. 2006). 
Worthen (2003) aptly highlighted the importance of management judgment to ensure effective forecasting besides sophisticated forecasting techniques. Thus, management commitment and belief in forecasting is important to ensure that business organizations can strategically adapt to the ever changing global business environment. Enron could have survived if management made more accurate predictions of the future (Michaluk 2002). Thus organizations must understand the value of forecasts and this is the gap identified and warranted by Lawrence et. al. (2006) to be further examined. This is where our conceptual framework will offer a direction for such investigation. As a result, we hope to make positive contributions in strategic adaptation, forecasting and management accounting literatures.

\section{A proposed conceptual forecasting framework}

Contingency theories postulate that the management style and organizational structure were influenced by various aspects of the environment: the contingency factors. There are numerous studies in this area, amongst others Downs \& Mohr 1976; Boeker 1989; Miller 1991. Whilst contingency theories focus on the factors outside the firm, the resource-based theory attempts to look at factors within the firms. This theory attempts to trace the sources of performance differences by looking within the firm. The RBV explains differential firms' success by investigating factors internal to the firm, which are terms of firm-specific resources. The resource-based theory of performance accentuates the structural characteristics of the firm and the environment in explaining performance (Bruderl et al. 1992). Another theory is the adaptation theory which assumes that organizations survive or fail as a function of their ability to read and interpret patterns in the environment and adapt over time (Morris \& Zahra 2000). It is a process of reciprocal adjustment between the organization and its environment. The reciprocity of the process presupposes that the organization modifies just as much as the environment (Lawrence \& Dyer 1981).

In institutional theory, a wide range of different views on organized human behavior are explained. Institutions can be defined as 'a way of thought or action of some prevalence and permanence, which is embedded in the habits of a group or customs of people' (Scapens 1994). This theory assumes that human action is in some way constrained by social structures that are the product of past social interactions. It focuses on the constraining dimension of the social context which has led to criticism that institutional theories underemphasize human agency (Powell \& Dimaggio 1991; Seo \& Creed 2002).

In addition to the above theories we will also use the stakeholder theory. This theory identifies the groups which have interests in the organization and recommend methods in which management give due regard to the interest of those groups (Freeman 1984). In understanding the performance concept, stakeholder theory states that the answer to how well an organization is performing depends upon who is posing the question or from whose point of view and thus needs a multiple constituency approach (Clarkson 1995).

This framework (see Figure 1) has the potential to be used to identify companies with high strategic adaptation abilities by using six performance measures derived from past empirical research studies as proxies. The proxies derived from Eunni's (2003) conceptual model, which are the independent variables, are described below:

- Longevity. This measure is derived from previous studies (Chandler 1990, 1994) which state that established companies are more likely to adapt better to changing circumstances than entrepreneurial companies. Longevity as a measure of the success of a firm's performance has been widely used in past research studies (Koberg et al. 2000).

- Sales growth. Firms with superior adaptation ability are expected to have sales growth rate higher than that of other surviving firms (Laitenan 2000).

- Market share. Market share has empirically been proven to be an important determinant of profitability (Schoffler 1977). Although subsequent studies have put a cap of $65-75 \%$ as the critical market share above which businesses may become less profitable (Schwalbach 1991), the importance of market share as a measure of success of a firm has not been empirically disproved.

- Market share change. Firms with superior adaptation ability not only are likely to have a higher market share but also are expected to increase their share of the market at a rate greater than other surviving firms (Chakravarty 1986).

- Price-to-Earnings Ratio. Besides the above measures, performance of a company can be gauged from how enthusiastic the investors are about a company and how confidence they have in the potential of a company can add to shareholder value. Market measures of performance should complement accounting measures for holistic assessment of firm's 


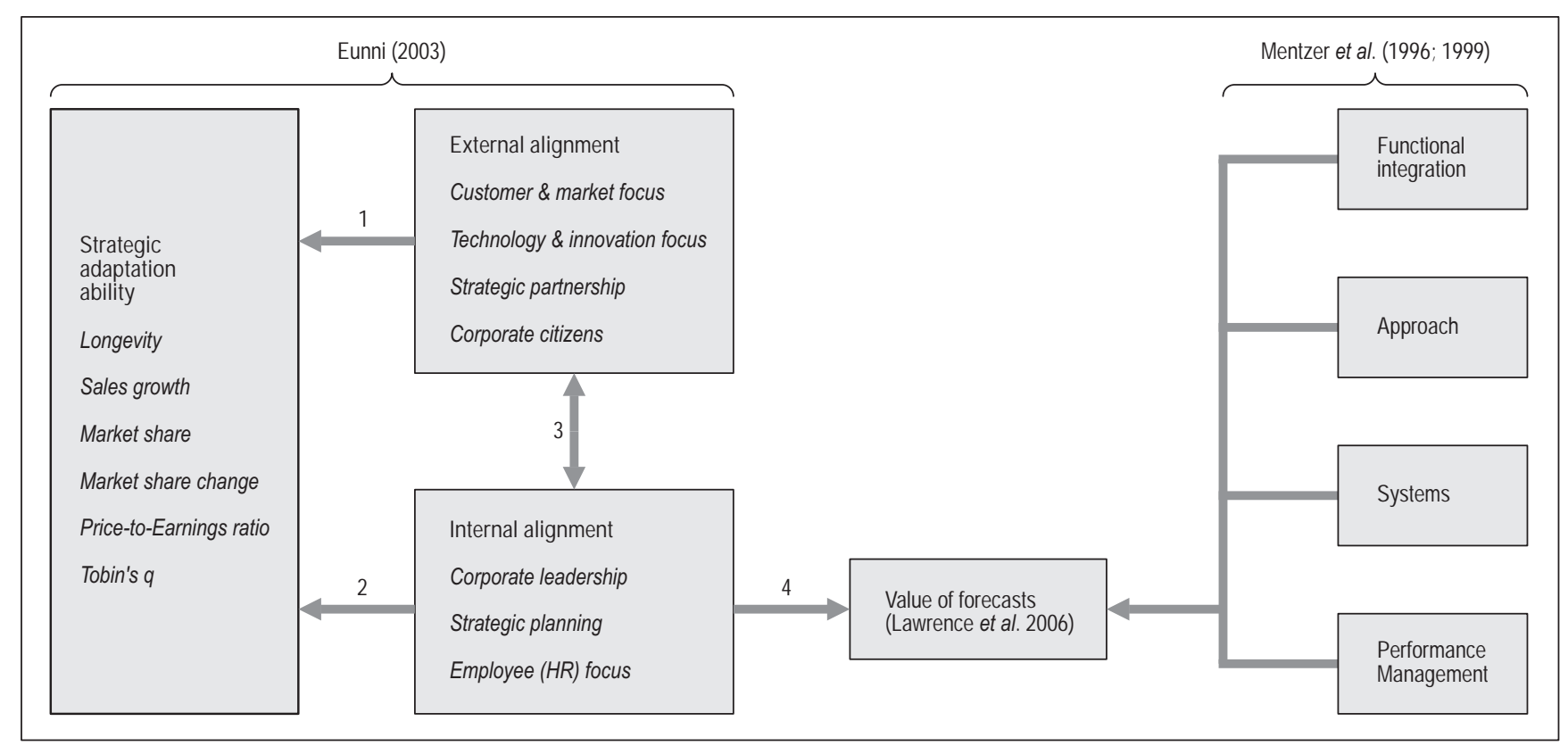

Strategic adaptation and value of forecasts: a conceptual framework (Faizal 2007)

(Inspired by and adapted from Eunni (2003), Lawrence et al. (2006), Mentzer et al. (1996; 1999))

performance. High performing companies in an industry are expected to have higher than average PE ratio (Siegel 2002).

- Tobin's q. While PE ratio captures investor's optimism given the earnings position, Tobin's q measures its manifestation in the total market value of the firm vis-à-vis the replacement cost of its assets. It is an important and widely used measure of performance in finance and strategy literature (McGahan 1999).

The additional constructs contained within the conceptual framework are detailed below.

- External alignment. The external alignment constructs are operationalizsed by delineating factors that enhance the ability of a firm to achieve fit with the environment. The factors evidencing the existence of external alignment in a firm identified from a survey of literature are customer and market focus (Brooksbank 1991), technology and innovation focus (Grant 1991), strategic partnership (Yoshino \& Rangan 1995) and corporate citizenship (Wood \& Jones 1995).

- Internal alignment. The internal alignment constructs are operationalized by identifying certain factors in a firm that evidence intra-firm coherence or fit between various structures and processes in order to position it better in relation to market opportunities. The factors are corporate leadership (Collins \& Porras 1994), strategic planning (Armstrong 1986b) and employee focus (HR) (Becker \& Gerhart 1996).
The second part of the conceptual framework uses Mentzer's model (1996; 1999). This model incorporated the managerial aspects of the sales forecasting process in four dimensions. For each dimension, there is a hierarchy of forecasting effectiveness divided into four stages.

- Functional integration dimension. This refers to the communication, coordination and collaboration (internal to firm), which are the key concepts in forecasting. Communication encompasses all forms of written, verbal, and electronic interaction among the functional business areas. Coordination is the formal structure and required meetings between two or more areas. Collaboration is an orientation among the areas toward common goal setting and working together.

- Approach dimension. This refers to what is forecasted and how it is forecasted (within the company). The two basic approaches highlighted in this model are top-down and bottom-up.

- Systems dimension. This dimension encompasses the computer and electronic communications hardware and software utilized to develop, analyze, and distribute forecasts.

- Performance measurement dimension. This dimension involves the metric (statistical or mathematical techniques) used to measure forecasting effectiveness and any information to explain performance.

Using this model, attempts could be made to signify the value of forecasts by analyzing the interrelationship 
between the four dimensions. This means, researchers could investigate the stage of forecasting effectiveness of a chosen company by analyzing the feedback from users of forecasting information and the forecasting process used by the company. It is from this investigation that we could ascertain how satisfied companies are with the information and the level of its accuracy. These two factors and maybe other organizational factors determine the usefulness and success of forecasting and thus indicate a "value" that we could objectively apply as a benchmark in our proposed "value grid". Level of accuracy of forecasts and firm's acceptability of the forecasts are important in determining the value of forecasts (Jain 2006).

\section{Conclusion}

It is hoped that our sample will show that companies with high strategic adaptation ability need to be further examined in order to understand and take on board how they withstand the volatile market through the conceptual framework offered. In this way, the study will provide better directions, driven by previous studies and current scenario, for companies to better adapt for strategic purposes towards an objective indicator of value of forecasts.

Enron could have been saved if a better forecasting system had been in place. The importance of forecasting must not be undermined especially in facing the uncertainties of globalization. This conceptual framework attempts to signify the value of forecasts and hopes to make scholarly and practical contributions in integrating the areas of management accounting, strategic adaptation and forecasting. In the process of this study, we have attempted to bridge the three literatures.

\section{References}

Armstrong, J. S. 1986a. The ombudsman: Research on forecasting: a quarter century review, 1960-1984, Interfaces 16(1): 89-109.

Armstrong, J. S. 1986b. The value of formal planning for strategic decisions: Reply, Strategic Management Journal 7: 183-185.

Armstrong, J. S. 2005. Strategic planning and forecasting fundamentals, in The Strategic Management Handbook. New York: McGraw Hill, 2-32.

Armstrong, J. S. (ed.). 1987. The Handbook of Forecasting: The Forecasting Audit. New York: John Wiley.

Aziz-Khairulfazi, R. 2004. An Empirical and Analytical Study of Forecasting Practices and Perceptions in the United Kingdom. University of Salford, UK.
Barney, J. 1986. Strategic factor markets: Expectation, luck, and business strategy, Management Science 42: 1231-1241.

Barney, J. 1991. Firm resources and sustained competitive advantage, Journal of Management Studies 17(1): 99-120.

Becker, B., \& Gerhart, B. 1996. The impact of human resource management on organizational peformance: Progress and prospects, Academy of Management Journal 42(5): 488-506.

Boeker, W. 1989. Strategic change: The effects of founding and history, Academy of Management Journal Special Issue: 131-149.

Brooksbank, R. W. 1991. Successful marketing practice: A literature review and checklist for marketing practitioners, European Journal of Marketing 25(2): 20-29.

Bruderl, J.; Preisendorfer, P.; Ziegler, R. 1992. Survival chances of newly founded business organizations, American Sociological Review 57(2): 227-242.

Chakravarty, B. S. 1986. Measuring strategic performance, Strategic Management Journal 7: 437-458.

Chandler, A. D. 1990. The enduring logic of business success, Harvard Business Review March/April: 66-77.

Chandler, A. D. 1994. The competitive performance of US industrial enterprises since the Second World War, Business History Review (Spring).

Child, J. 1997. Strategic choice in the analysis of action, structure, organizations and environment: Retrospective and prospect, Organization studies 18(1): 43-76.

CIMA. 2000. Management Accounting Official Terminology. London: CIMA.

Clarkson, M. B. E. 1995. A stakeholder framework for analysing and evaluating corporate social performance, Academy of Management Review 20(1): 92-117.

Cleary, J. P.; \& Lavenbach, H. 1982. The professional forecaster. Belmont, CA: Lifetime Learning Publications.

Collins, J. C.; \& PORRAS, J. 1994. Built to last: Successful habits of visionary companies. New York: Harper Business.

Cox, J. E. 1987. An Assessment of books relevant to forecasting in marketing, International Journal of Forecasting 3: $515-527$.

Cox, J. E. 1989. Approaches for improving salespersons' forecasting, Industrial Marketing Management 18: 307-311.

Downs, G. W.; \& Mohr, L. 1976. Conceptual issues in the study of innovation, Administrative Science Quarterly 21: 700-714.

Eunni, R. V. 2003. Strategic adaptation in a rapidly changing industry: an empirical study of the telecommunications equipment industry in the United States (1990-1999). Boston, USA. 
Fildes, R.; \& Hastings, R. 1994. The organization and improvement of marketing, Journal of the Operations Research Society 45(1): 1-16.

Focus Reports LLC. 2006. Special report: Malaysia, Oil and Gass Financial Journal 3: 1-12.

Freeman, R. E. 1984. Strategic Management: A Stakeholder Approach. Boston: Pitman.

Fuller, T. 2000. Petronas ignores globalization fears to make its mark: Malaysia's little oil giant, International Herald Tribune.

Ginevičius, R.; Korsakienè, R. 2005. Explotation strategy: objectives, competencies and competitive advantage, Business: Theory and Practice 6(3): 17-25.

Grant, R. M. 1991. The resource-based theory of competitive advantage: Implications for startegy formulation, California Management Review 33(3): 115-135.

Green, Y. N. J. 2001. An exploratory investigation of sales forecasting process in the causal theme and family dining segments of commercial restaurant corporations. University of Virginia, USA.

Hoyos, C. 2007. The new seven sisters: Oil and gas giants dwarf western rivals. The Financial Times.

IFAC. 1998. Evolution of Management Accounting March.

Jain, C. 2006. Benchmarking forecasting practices in America, The Journal of Business Forecasting 25(4): 9.

Jayasankaran, S. 2004. Petronas strikes gold, Far Eastern Economic Review.

Johnson, H. T.; \& Kaplan, R. S. 1987. The rise and fall of Management Accounting, Management Accounting June: 22-30.

Koberg, C.; Chesley, J. A.; \& Heppard, K. A. 2000. Adaptive latitude: Environment, organization and individual influences, Journal of Business Research 50: 259-272.

Laitenan, E. K. 2000. Long-term success of adaptation strategies: Evidence from Finnish companies, Long Range Planning 33(6): 259-272.

Lawrence, M.; Goodwin, P.; O’Connor, M.; \& Önkal, D. 2006. Judgmental forecasting: A review of progress over the last 25 years.

Lawrence, P.; \& Dyer, D. 1981. Toward a theory of organizational and industrial adaptation. Boston: Harvard University.

Makadok, R.; \& Walker, G. 2000. Identifying a distictive competence: Forecasting ability in the money fund industry, Strategic Management Journal 21(8): 493-518.

Makridakis, S.; Wheelright, S.; \& Hyndman, R. 1998. Forecasting: Methods and applications: John Wiley and Cons.

Makridakis, S.; \& Wheelwright, S. 1977. Forecasting: Issues and challenges, Journal of Marketing 24: 24-38.

Mcgahan, A. M. 1999. Competition strategy and business performance, California Management Review 41(3): 74-101.
Mentzer, J.; Kahn, K.; \& Beinstock, C. 1996. Sales forecasting benchmarking study. Knoxville: University of Tennessee.

Mentzer, J.; Kahn, K.; \& Beinstock, C. 1999. Benchmarking sales forecasting management, Business Horizons 42(3): 48-56.

Mentzer, J. T.; \& Gomes, R. 1994. Further extensions of adaptive exponential smoothing and comparison with the M-competition, Journal of the Academy of Marketing Science 22: 372-382.

Mentzer, J.; \& Cox, J. 1984. Familiarity, application and performance of sales forecasting techniques, Journal of Forecasting 3: 27-36.

Menzter, J.; \& Kahn, K. 1995. Forecasting technique familiarity, satisfaction, usage, and application, Journal of Forecasting 14: 465-476.

Michaluk, G. 2002. The Enron fiasco: So many lessons. Business Week.

Miller, D. 1991. Stale in the saddle, Management Science 37: $34-52$.

Morris, M. H.; \& Zahra, S. 2000. Adaptation of the business concept over time: The case of historically disadvantaged South African owner/manager, Journal of Small Business Management 38: 92.

Naylor, T. H. 1983. Strategic planning and forecasting, Journal of Forecasting 2: 109-118.

Nelson, R.; \& Winter, S. 1982. An evolutionary theory of economic change. Belknap Press.

Porter, M. 1996. What is strategy? Harvard Business Review 74(6): 61-78.

Powell, W. W.; \& Dimaggio, P. J. 1991. The new institutionalism in organizational analysis. Chicago: University of Chicago Press.

Prahalad, C.; \& Hamel, G. 1990. The core competence of the corporation, Harvard Business Review 63(3): 79-91.

Sanders, N. R.; \& Mandrodt, K. B. 1994. Forecasting practices in US corporations: Survey results, Interfaces 24(2): 92-100.

Scapens, R. W. 1994. Never mind the gap: Towards an institutional perspective of management accounting practices, Management Accounting Research 5(3/4): 13-21.

Schoffler, S. 1977. Cross-sectional study of strategy, structure and performance: Aspects of PIMS program. Indiana: Indiana University Press.

Schwalbach, J. 1991. Profitability and market share: A reflection of the functional relationship, Startegic Management Journal 12: 299-306.

Seo, M. G.; \& Creed, W. E. D. 2002. Institutional contradictions, praxis and institutional change: a dialectical perspective, Academy of Management Review 27(2): 22-47.

Shaw, R. 2007. Forward-looking finance, Financial Management CIMA. 
Siegel, J. J. 2002. The rise in stock valuations and future equity returns, The Journal of Investment Consulting 5 (1 Jun./Jul.).

Smith, C. D. 2000. Assessing the value of improved forecasting management. University of Tennessee, USA.

Steiner, G. 1979. Strategic planning. New York: Free Press.

Strauss, A.; \& Corbin, J. 1998. Basics of qualitative research: Techniques and procedures for developing grounded theory. Thousand Oaks, California: Sage.

Teece, D. 2000. Managing intellectual capital: Organizational, strategic, and policy dimensions. Oxford University Press.

Teece, D.; Pisano, G.; \& Shuen, A. 1997. Dynamic capabilities and strategic management, Strategic Management Journal 18: 509-533.

Thompson, A.; \& Strickland, A. 1987. Strategic Management (4th ed.). Plano, TX: Business Publications.

Venkaratman, N. 1990. Performance implications of strate- gic coalignment: A methodological perspective, Journal of Management Studies 27(1): 19-41.

Wallace, T. 1996. APICS: The performance advantage, Forecasting 101(6): 80-81.

Wood, D. J.; \& Jones, R. E. 1995. Stakeholder mismatching: A theoretical problem in empirical research in corporate social performance, International Journal of Organizational Analysis 3: 229-267.

Worthen, B. 2003. Future results not guaranteed: Contrary to what vendors tell you, computer systems alone are incapable of producing accurate forecasts, CIO 16(19): 1.

Wright, D. J. 1988. Decision support oriented sales forecasting methods, Journal of the Academy of Marketing Science 16(4): 71-78.

Yin, R. K. 2003. Case study research: Design and methods. London: Sage.

Yoshino, M. Y.; \& Rangan, U. S. 1995. Strategic alliances: An entrepreneurial approach to globalization. Boston: Harvard Business School Press. 